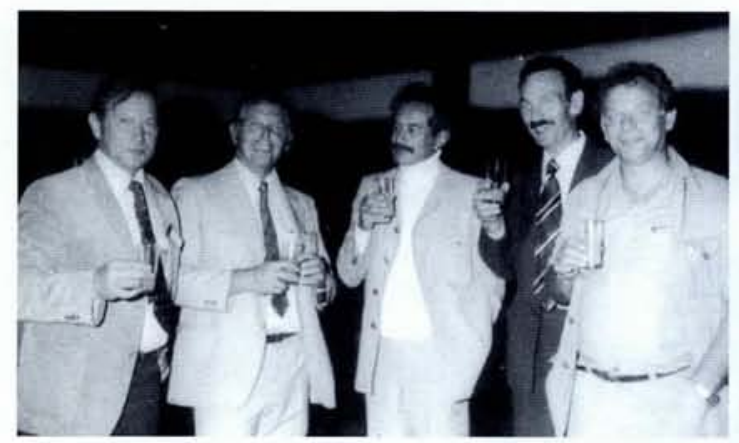

the co-operation of the Israeli Physical Society. By 1989, such incidents had become sufficiently infrequent that the Executive Committee decided to dissolve the scientific freedom committee, and Charap was appointed to the Advisory Committee on Physics and Society, with special responsibility for questions of scientific freedom. Since he is also a member of the At the EPS-5 General Conference in Istanbul: from the left, A.B. Berezin from Leningrad (now St. Petersburg), W.J. Merz (Chairman of the Conference Committee, 1976-82, and EPS Secretary. 1983-89) from the RCA Laboratories in Zurich, J.M. Charap, a turkish politician, and Zh.I. Alferov from the Joffe Institute in Leningrad. was never any question over persecuted physicists in any part of Europe, or indeed further afield, being given support; the dilemma lay in the extent of this support. Dictatorships of any kind are rarely sensitive to ethical considerations, but they may be sufficiently pragmatic to act in a humane fashion when they perceive it to be in their own interest. The communist governments of eastern Europe were interested in maintaining scientific contacts with the rest of the world, largely in the hope of propping up their disintegrating economic systems, and were willing to pay a price for doing so. This price could not, however, be set too high. In retrospect, it is clear that the EPS came close to fission in the cases of both Janouch and Sakharov, but by remaining intact, the Society was able to help them more than a more uncompromising condemnation of their persecutors would have allowed. We did not experience many examples, either by the Society or by individual physicists, of the self-indulgent protest whose principal consequence is to induce a feeling of moral superiority on the part of the protagonist. I believe that the leadership of the EPS generally acted wisely in not cancelling conferences and other functions, even though they were sometimes sorely provoked. On the other hand, the protests and boycotts by individuals were in many cases appropriate and useful in representing the indignation of the physics community.

I cannot recall any physicist who behaved in a blatantly opportunistic manner or without ethical scruples during these difficult years. Some of us in the West may have shown too little understanding of the problems of our eastern colleagues, a small number of whom may have given their career priority over their human obligations, but there was always a feeling, mostly expressed in private, that we were all on the same side. The contact and understanding which was maintained between individuals and societies through severe stresses has placed the EPS in an ideal position to play its essential rôle in strengthening physics throughout the whole of the continent in the future.

\title{
Ensuring East European Participation
}

\section{F. Janouch recalls many of the difficulties.}

A photograph taken in 1982 of the Institute of Physics of the Czechoslovak Academy of Sciences that housed the EPS Branch Secretariat. The Institute belonged to the Academy's main complex on Na Slovance on the outskirts of Prague.

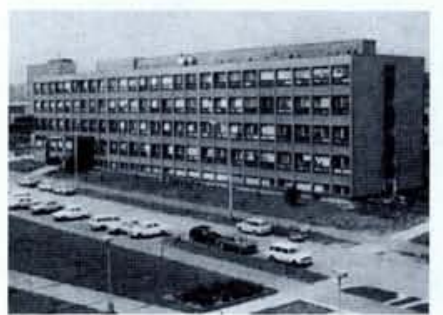

Although the second half of the 1960's was a relatively liberal period in the Soviet bloc, it was not obvious that the various countries would join the moves to form EPS, as this depended on high-level decisions taken in the Soviet Union. It was also clear that EPS would be less attractive if physicists from eastern Europe were not involved. Their participation in the Steering Committee formed in 1966 was rather sporadic, and only three were present at the Committee's third meeting in January 1968, although all national societies and academies had been invited (for the first time). Jan Tauc was appointed to represent the Czechoslovak Academy of Sciences in early 1968, and I was informed at about the same time of the plans to establish EPS. We both became enthusiastic supporters, and I was co-opted in March to the Bureau of the Steering Committee.

While the political atmosphere allowed Czechoslovakian physicists to play an active rôle, it was clear that money was an obstacle since access to hard currencies was restricted. Accordingly, some of us invited the Committee to meet in Prague in May 1968. Behind the scenes efforts by the Czechoslovak Academy of Sciences to persuade academies and national physical societies from the Soviet bloc to send delegates were successful (20 attended, and only Bulgaria was not represented).

There was a separate meeting of the east European contingent where a joint policy towards the EPS should have been worked out. Various attitudes were expressed and in the main, the idea of an EPS was strongly supported, physicists correlating its creation with the opening up of contacts with western Europe. For some delegates, the concept that individuals could become members of an international society seemed strange, contradicting the rules governing relations with foreign organizations; they preferred an umbrella association. For the Soviet Union, 
membership implied a structural problem since a national physical society did not exist and the only representation was through the USSR Academy of Sciences.

Payment of fees in hard currencies would be difficult so the Czechoslovak delegates proposed the creation of a branch secretariat in Prague, where the Academy was ready to provide facilities for which the Soviet bloc countries could pay their contributions in non-convertible roubles. As it turned out, the complicated financial relations among COMECOM countries never allowed this to happen.

The Prague meeting of the Steering Committee affirmed European cultural unity and the need for EPS. Attended by 52 physicists from 18 countries, the meeting was supposed to be the last before the formal founding of the Society, and it would be fair to say that it was decisive in persuading eastern Europe to join EPS. Still, the position of "big brother" was not yet clear so further discussions with the Soviet Academy of Sciences were necessary. I can report on two of the many steps taken in this direction during the next few months. In the middle of July, Viki Weisskopf and I visited a Vice-President of the Academy where discussions concentrated on Soviet participation. The official attitude was quite negative. A week or two later, Tauc was approached at a conference in Moscow by an Academy official, who took him to meet a member of the Academy's Presidium responsible for foreign relations. After explaining why it was unnecessary to create the EPS and the problems it could provoke, he unexpectedly finished by saying that Czechoslovakia and other countries had decided to join, and that the Soviet Union, in not wanting to break the unity of the socialist bloc, would also join.

\section{Czechoslovakia Invaded}

The invasion of Czechoslovakia on 21 August 1968 changed the situation. I was due to leave for a meeting of the working group for an EPS newsletter, but was wakened by a telephone call shortly before $1 \mathrm{a}$.m. informing me that the country was being occupied, the Prague airport was closed, and I should stay where I was.

Nevertheless, a week later I was able to leave for Vienna to finish editing the proceedings of a conference, where I immediately contacted the secretariat. After consultations with Bernardini it was decided to convene a meeting of the Bureau for 5 September at the Institut Battelle. All seven members felt that it was impossible to ignore what had happened in Czechoslovakia, and after a long discussion proposed that a letter should be sent to physicists from the five countries taking part in the invasion informing them that they were not welcome at the inaugural meeting of EPS. This was scheduled for 25-26 September in Geneva and invitations had been sent out before 21 August. A letter drafted by Josef-Maria Jauch was agreed on ready for Bernardini's signature the next day.

I myself had sent emotional letters to colleagues in the West asking them what they intended to do, and had even asked them to consider boycotting scientists from the Soviet Union. I also wrote to a dozen or so members of the Soviet Academy. It was difficult for me to accept that the EPS could be created a month after such brutal happenings as if nothing had happened. Jauch's draft at least meant some action. Nevertheless, doubts remained as it was clear that Bernardini's letter could endanger the foundation of EPS.

Later that day I called Tauc in Prague to discuss the Bureau's decision. The situation had calmed down somewhat, and Tauc expressed doubts that the letter should be sent. He said that Czechoslovakia would be able to join the EPS in September, but he was not sure if it could be done later. Members of the Bureau went to the station to catch Bernardini, who was leaving for Pisa by the night train, and it was decided to involve the entire Steering Committee. The next day he called an extraordinary session of the Committee to be held at CERN on 12 September.

The most important point on the agenda reads: "New elements concerning the desirability of constituting the European Physical Society with special reference to recent events." About 25 members took part and others sent cables expressing their views. The meeting was dominated by Bernardini's great Florentine spirit, without whose skill, vision and will to create the EPS it would have been difficult to reach consensus. He felt one should perhaps wait until the return to normality - but it was very hard to give a definition of normality, which varies very much from one country to another.

Being the only Czechoslovak present, I was listened to attentively. It was not easy for me to agree to go on with plans to establish the Society, yet I did so believing that, in the long run, an all-Europe organization of physicists would play an important rôle in overcoming the situation in Europe. It was unanimously agreed to proceed with the foundation of the Society as planned, without discriminating against any nation. The Steering Committee was undoubtedly influenced by a letter from Weisskopf, in which he argued: "This incredible act of military force has set back the cause of productive collaboration between east and west, but it makes it all the more important to strengthen the bonds between scientists." The invitations sent out in July were confirmed, but in the end the Soviet bloc was only represented at the inaugural meeting by four countries.

I was elected the first EPS Vice-Secretary responsible for the branch secretariat in Prague. Although the situation in Czechoslovakia was entirely different from that obtaining when the branch was discussed, we made genuine (even desperate) efforts to maintain activities. From early 1969 , we had a small office provided by the Institute of Physics in Prague and the Czechoslovak Academy funded the operation. However, we were under increasing pressure from so-called normalization (i.e., a restoration of a Stalinistic regime). There was one employee and activities started with publications and their distribution. Four information booklets and a circular about a summer school were produced. The EPS logo, still used today, was also created in Prague.
B.P. Gregory (second from the left), the Director-General of CERN, chairing the plenary session of the Steering Committee held at CERN on 26 September 1966. G. Bernardini is on his right, and to his left are J.-M. Jauch, W. Genter (hidden), G.-J. Béné (facing the camera), and F. Janouch.
In the centre, I. Ursu, the EPS President from 1976-78, at the Ettore Marjorana Centre in Erice during a meeting of the Executive Committee in November 1977. From the left, A. Janner (first Chairman of the Education Committee), E.N. Shaw (the Editor of Europhysics News), I. Ursu, G. Thomas (the Executive Secretary), and A. Zichichi (EPS President, 1978-80).

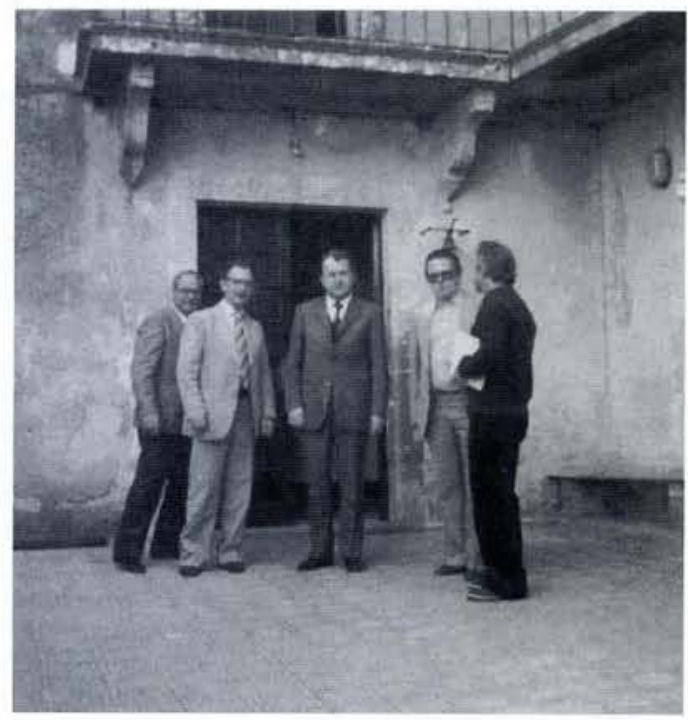




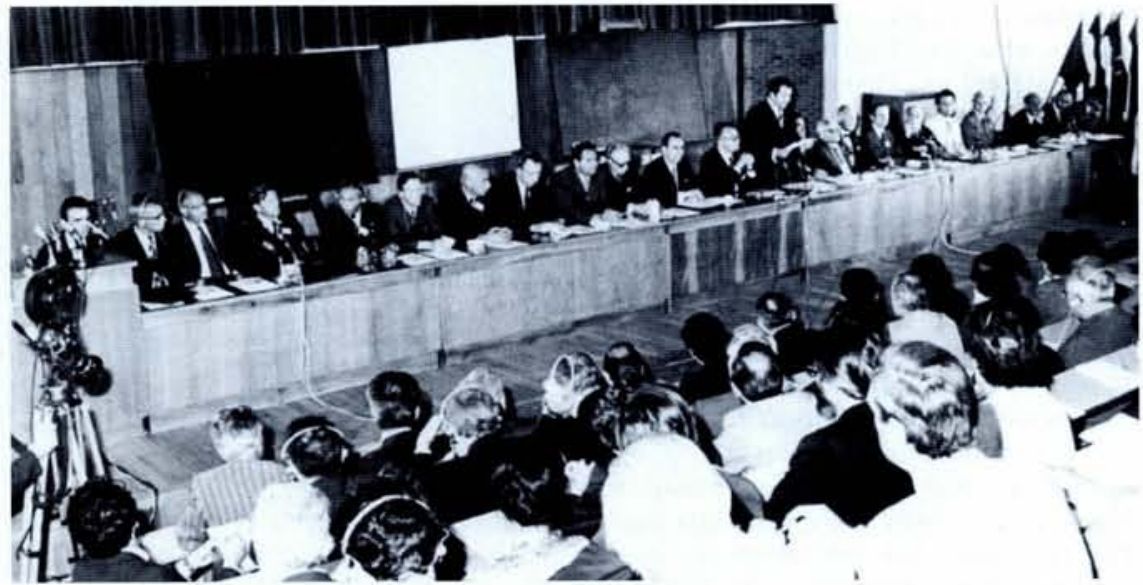

The opening of the third General Conference in Bucharest in September 1975.
My passport was confiscated in the autumn of 1969 and from October I was prevented from participating in EPS activities outside Czechoslovakia (I was to lose my position at the Nuclear Research Institute in 1970 and I remained unemployed until 1974). The secretariat was thus gradually paralyzed and Council was informed in 1973 that the Academy had decided to close it down.

\section{Continuing Difficulties}

In the spring of 1973, the Czechoslovak Academy, wishing to improve its reputation abroad following several dismissals similar to mine, invited the EPS to hold the 3rd General Conference in Prague in 1975. The EPS President, H.B.G. Casimir, welcomed the invitation in his reply to the Academy's President, but indicated that Janouch had no possibility to earn a living as a physicist. He wrote: "I wonder whether you have any advice or information to give on this matter." The response was cold: "Owing to the difficulties you have met while discussing our original proposal... I sincerely regret to inform you that we came to a conclusion to cancel our proposal..." Casimir's subsequent attempts to discuss the matter in Prague were unsuccessful. East European members supported Casimir's approach, and I. Ursu from Romania came up with an invitation to hold the conference in Bucharest, where infractions of human rights at least did not generally involve physicists.
In the autumn, a Czechoslovakian delegation proposed at a meeting of east European representatives that physicists should either leave EPS or at least cool down relations because of the support for Janouch. Rejection of both proposals and the transfer of the General Conference to Bucharest probably induced the Czechoslovak Academy and/or the authorities to allow me to leave the country, which I did it at the end of 1973 with my family (with a passport valid for 5 years, only to be deprived of citizenship in 1975).

I was elected to the EPS Council as a delegate of the Individual Ordinary Members in 1983, the year before the 6 th General Conference was scheduled to take place in Prague following an invitation from the Czechoslovak Academy. Although assurances were given about entrance visas, my application was rejected. Following protests, the President of the Academy stated in a widely circulated letter "that the activities of Professor Janouch have threatened to split the EPS". The Executive Committee made repeated efforts to persuade the authorities to change their minds, as did the conference organizers. But they remained obdurate and it was with much hesitation that the decision was taken to go ahead with the meeting, the overriding argument being that whilst the principle of free access by "classes" of physicists was inviolate, the EPS could not provide against States designating individuals as persona non grata. Some felt the Executive's attitude to be complaisant: I campaigned against it as did John Ziman who was scheduled to present the Powell Memorial Lecture and who refused to attend, letting this be widely known. Nevertheless, EPS gave considerable publicity to the visa refusal, the President issued a statement at the General Meeting, and the Executive appointed a committee under John Charap to look into the matter. It concluded that the reaction could have been more vigorous and called for vigilance in the future. But it had no simple formula to offer.

Europe has since changed considerably. The problems I write about seem now to belong to the past. I hope that EPS can concentrate on physics and its position in society, for the issues may turn out to be as difficult to tackle as those dealt with during the first 20 years.

\section{Anticipating EPS on a Reduced Scale}

\section{G.-J. Béné, Geneva}

I was informed at the end of the summer of 1966 of the consultations undertaken by Bernardini in what G. Saragat, the President of the Republic of Italy, put it in his telegram to the Pisa meeting in April 1966 as "the possibility of forming a single and free association of European physicists". The proceedings of this meeting, distributed the following September, had the merit of clearly posing the problem which was soon to be at the centre of the often lively discussions of the Steering Committee; should we found a new association with (physical or legal) individual members, or should we opt for a looser federation of national associations? The question was not simple and I felt then that the experience of the Groupement Ampère might well be of some use in this discussion.

\section{The Groupement Ampère}

Creating the Group was especially laborious for it was necessary to find a host laboratory, a source of finance, etc. But the problems were clear: in the aftermath of World War II, laboratories, notably those removed from the main cities, lacked equipment, literature and many other resources. R. Freymann from Paris had the idea at a conference in Oxford in 1948 to create a liaison bulletin to exchange information and to ask for support from the Centre National de la Recherche Scientifique (CNRS) in France to purchase surplus American equipment for joint use.

The perspective was a national group that Freymann immediately baptised AMPERE (atomes et molécules par études radio-électriques). Decisive steps were taken thanks to 